\title{
Bisphosphonate-Related Osteonecrosis of the Jaw Bones in a Patient with Ankylosing Spondylitis Receiving Anti-Tumor Necrosis Factor Treatment
}

\author{
Anti-Tümör Nekroz Faktör Tedavisi Alan Ankilozan Spondilitli Bir Olguda Gelişen \\ Bifosfonatla İlişkili Çene Osteonekrozu
}

\author{
Banu İșLETEN, ${ }^{1}$ Simin HEPGÜLER, ${ }^{1}$ Selen BAYRAKTAROĞLU, ${ }^{2}$ Gökhan KESER ${ }^{3}$ \\ ${ }^{1}$ Department of Physical Medicine and Rehabilitation, Medical Faculty of Ege University, İzmir, Turkey; \\ ${ }^{2}$ Department of Radiology, Medical Faculty of Ege University, İzmir, Turkey; \\ ${ }^{3}$ Department of Internal Diseases, Medical Faculty of Ege University, İzmir, Turkey
}

\begin{abstract}
Bisphosphonate-related osteonecrosis of the jaw bones is a rare, but well-recognized pathology, occurring mainly in patients receiving parenteral and high doses of bisphosphonates for the treatment of skeletal metastasis and/or hypercalcemia associated with cancer. However, to a lesser extent, this complication may also occur in patients receiving oral bisphosphonates for the treatment of osteoporosis. In this article, we present a 58-yearold female patient with ankylosing spondylitis (AS) who developed mandible osteonecrosis following long-term oral alendronate treatment for osteoporosis. Dental tooth extraction possibly triggered the occurrence of mandible osteonecrosis in this patient. This patient is notable for receiving concomitant anti-tumor necrosis factor (anti-TNF) treatment. To our knowledge, occurrence of bisphosphonate-related jaw osteonecrosis in a patient with AS receiving concomitant anti-TNF treatment has not been reported previously in the literature.
\end{abstract}

Key words: Ankylosing spondylitis; bisphosphonate; jaw osteonecrosis.

Bisphosphonates, the potent inhibitors of osteoclastmediated bone resorption, are mainly used in the treatment of metabolic and oncological diseases involving the skeleton, including osteoporosis, Paget's disease, and metastatic bone lesions. ${ }^{[1]}$ They have a high affinity for hydroxyapatite bone mineral
Bifosfonat ile ilişkili çene osteonekrozu nadir görülen ancak iyi bilinen bir durumdur ve özellikle kanser ile ilişkili hiperkalsemi veya iskelet metastazı için parenteral ve yüksek dozlu bifosfonat tedavisi alan olgularda meydana gelmektedir. Ancak, daha düşük bir oranda olmakla birlikte, bu komplikasyon osteoporoz tedavisi için oral bifosfonat kullanan hastalarda da meydana gelebilmektedir. Bu makalede osteoporoz nedeniyle uzun süreli oral alendronat tedavisi gördükten sonra çene osteonekrozu gelişen ankilozan spondilitli (AS) 58 yaşında bir kadın olgu sunuldu. Diş çekimi olasılıkla bu hastada çene osteonekrozu gelişimini tetiklemiştir. Bu hasta kullanılan anti-tümör nekroz faktör (anti-TNF) tedavisi ile de dikkat çekmektedir. Bildiğimiz kadarıyla, antiTNF tedavisi almakta iken bifosfonat ile ilişkili çene osteonekrozu gelişen AS'li bir olgu henüz literatürde bildirilmemiştir.

Anahtar sözcükler: Ankilozan spondilit; bifosfonat; çene osteonekrozu.

surfaces, especially in regions with high boneremodeling. A subgroup of these agents known as aminobisphosphonates, which includes alendronate, also inhibits the osteoclastic enzyme known as farnesyl pyrophosphate (FPP) synthase, thereby maximizing their antiresorptive potential. ${ }^{[2]}$ 
Oral bisphosphonates used for the treatment of osteoporosis are generally well tolerated with some predictable side effects, such as gastrointestinal intolerance. However, in recent years, bisphosphonaterelated osteonecrosis of the jaw (ONJ) has also appeared in the literature as a rare but serious side effect of bisphosphonate therapy, although a direct causative relationship has not been demonstrated.

Ruggiero et al ${ }^{[3]}$ reported this complication first in 2003. Osteonecrosis of the jaw is currently defined as an area of exposed bone in the maxillofacial region that has not healed within eight weeks after identification by a healthcare provider in a patient who is receiving or has been exposed to a bisphosphonate and has not had radiation therapy to the craniofacial region. ${ }^{[4]}$ Most of the reported cases are cancer patients receiving parenteral high doses of bisphosphonates, with osteoporosis patients receiving oral bisphosphonates being the next highest group.

Hereby, we present a female with ankylosing spondylitis (AS) who developed mandible osteonecrosis after long-term oral alendronate treatment for osteoporosis. Dental tooth extraction preceded the occurrence of mandible osteonecrosis in this patient, who is also notable for receiving concomitant anti-tumor necrosis factor (anti-TNF) treatment for three years.

\section{CASE REPORT}

In September 2008, a 58-year-old female diagnosed with AS in 1973 was referred to Ege University Hospital, Department of Physical Medicine and Rehabilitation complaining of pain and discomfort in the right mandible. These symptoms had started in May 2008 following a tooth extraction. The extraction socket did not heal, even after eight weeks, despite antibiotherapy. Besides the pain and discomfort, she experienced the presence of some particles in the tooth extraction socket of her right mandible which were probably autogenous bone. A panoramic radiograph was taken 10 weeks later in July 2008 which revealed irregularity and diffuse sclerotic bone changes in the trabecular bone structure of the right mandible as well as a bony defect at the level of the extraction socket (Figure 1). A sample obtained from the exposed area was sent for culture to the microbiology laboratory due to the suspicion of dental infection/abscess. Oral flora microorganisms grew in the culture.

Her past medical history related with AS treatment documented that she had received primarily indomethacin between 1973 and 1996. In addition, during her peripheral arthritis attacks, she had intermittently received prednisolone starting with $20 \mathrm{mg} /$ day with doses tapering and completely stopping after a few months. In 1988, she had surgery for a total hip replacement.

In 1996, methotrexate (MTX) and sulphasalazine (SSZ) were commenced. However, MTX was discontinued due to hepatic side effects. Because of the clinical disease progression and activity, antiTNF treatment (etanercept $25 \mathrm{mg}$ twice weekly) was started in April 2004. A tuberculin skin test was negative, so latent tuberculosis (TB) prophylaxis was not given. She benefited from etanercept and remained on this treatment for more than three years until September 2008.

She received bisphosphonate treatment continuously for 10 years between 1998 and 2008 because of osteoporosis. Oral alendronate had been used as $10 \mathrm{mg} /$ day in the first five years, and when once-weekly doses became available, she received $70 \mathrm{mg} /$ week for the remaining five years. Although past bone densitometry reports were not available, current $t$ scores were -3.2 in the lumbar region and -1.5 in the femoral regions.

A recent physical examination revealed that besides the mandible problems, the patient's blood pressure, pulse, and body temperature along with her cardiac, respiratory, and abdominal systems were within normal limits. In a locomotor system examination, cervical and lumber ranges of motions were quite restricted. Tragus-wall distance was $18 \mathrm{~cm}$, lombar flexion $0 \mathrm{~cm}$, cervical rotation $0 \mathrm{~cm}$, lumber lateral flexion $5 \mathrm{~cm}$, and intermalleolar distance $20 \mathrm{~cm}$. The Bath Ankylosing Spondylitis Disease Index (BASDI) and Bath Ankylosing Spondylitis Functional Activity Index (BASFI) scores were 4.74 and 9.21, respectively.

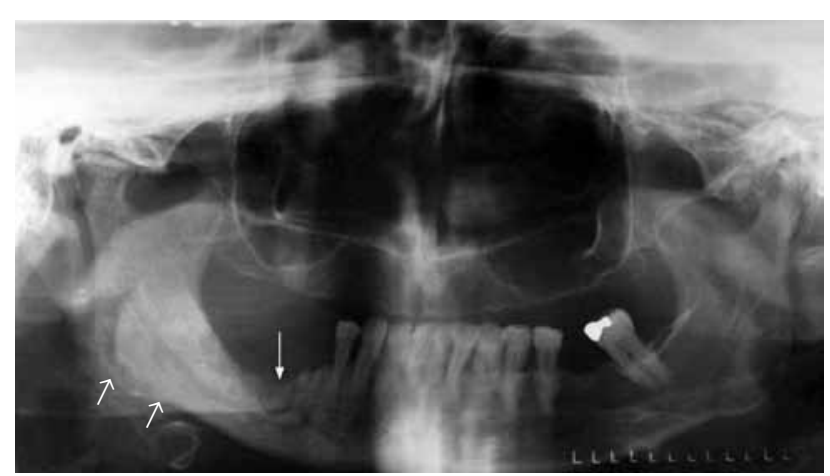

Figure 1. Panoramic radiograph of the patient showing diffuse sclerotic bone changes posterior to the right mandible around the first premolar teeth (short white arrows). There is a bony defect at the level of the extraction socket (long white arrow). 


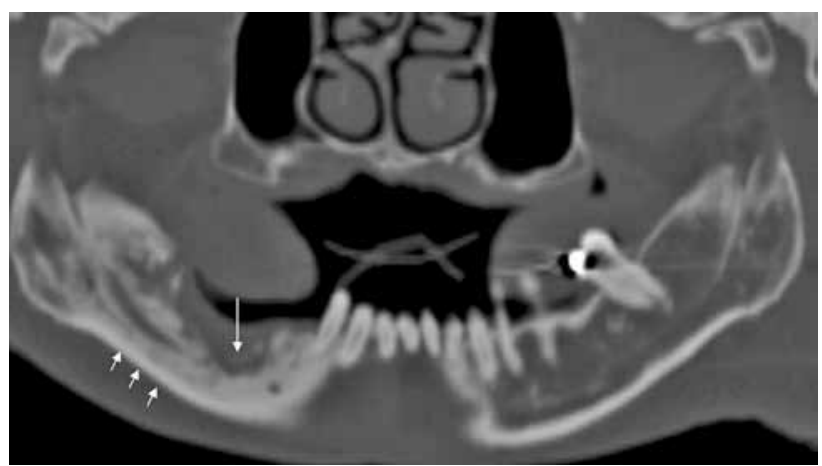

Figure 2. Corresponding curved pseudo-panaromic reformatted computed tomography images confirm the sclerosis in the right hemi-mandible (short white arrows) and osteolytic changes (long white arrow).

Besides a mild elevation in acute phase reactants, routine biochemistry and full blood count examinations were within normal limits.

Since she had had a history of etanercept treatment for three years, an autoantibody profile was also ordered. She was found to have positive speckled antinuclear antibody (ANA) with a $1 / 40$ titer; other autoantibodies including antiphospholipid (aPL) antibodies were negative. The autoantibody profile was not available before the etanercept treatment began.

Together with the past history of long-term alendronate treatment and occurrence after tooth

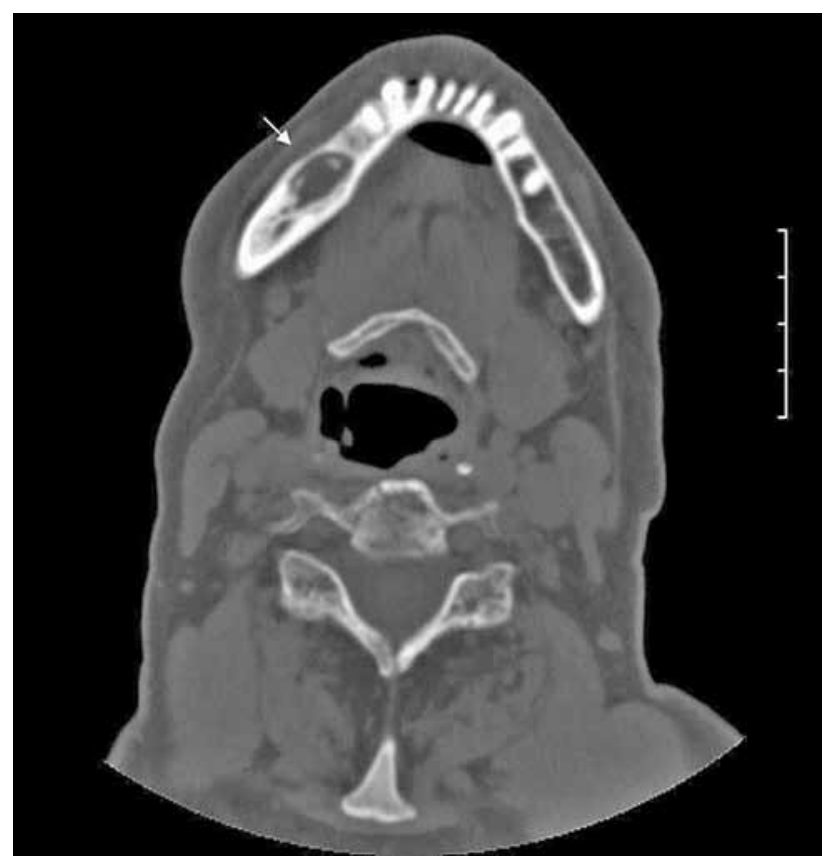

Figure 3. Axial bone window computed tomography scan of the mandible shows the osteolytic area (white arrow) surrounded by sclerotic changes at the right mandible corpus. The cortical lamina is intact, and there is no periosteal reaction. extraction, relevant clinical symptoms and conventional radiographic findings led to the suspicion of $\mathrm{ONJ}$ in this patient. We immediately ordered dental computed tomography (CT) which revealed sclerosis and osteolytic changes in the right mandible. This confirmed the diagnosis of osteonecrosis (Figures 2, 3). The patient also consulted with dental surgeons, and since there was no pathologic fracture, extra-oral fistulae, or osteolysis extending to the inferior border of the mandible, the disease was accepted to be in the second stage. Surgery was not recommended, and conservative management was started. The patient was advised to discontinue the alendronate treatment, and the etanercept treatment was also stopped. A good oral hygiene regimen using antibacterial tooth rinse was recommended. Her complaints and symptoms alleviated gradually. A control panoramic radiography taken after one year of bisphosphonate withdrawal displayed healing of the exposed bone (Figure 4).

Currently, she is receiving only indomethacin supp $100 \mathrm{mg} /$ day for AS along with $600 \mathrm{mg} /$ day calcium and $400 \mathrm{IU} /$ day vitamin D for osteoporosis.

\section{DISCUSSION}

The present case report describes the occurrence of $\mathrm{ONJ}$ in an elderly woman with AS who received longterm oral alendronate for osteoporosis treatment. This patient had had a history of concomitant etanercept treatment for more than three years. Unlike high doses of bisphosphonates given by the intravenous route, as in the case of cancer patients, the prevalence of ONJ due to oral bisphosphonates for osteoporosis treatment is very low and reported to be $0.00038 \%{ }^{[5]}$ To our knowledge, the occurrence of this very rare complication in a patient with AS receiving concomitant etanercept treatment has not been previously reported in the literature.

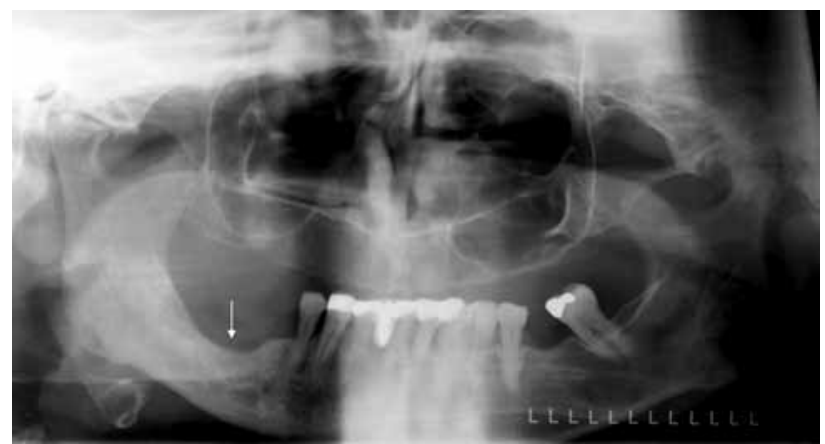

Figure 4. Panoramic radiograph of the patient taken after one year showing the healing of the bony defect (white arrow). 
In the present case, the diagnosis of ONJ was made based on the presence of relevant clinical and radiological findings as well as the past history of oral alendronate treatment for 10 years and occurrence after tooth extraction. These features are consistent with the data in the literature documenting that being an older female and having long term bisphosphonate treatment (generally longer than 3 years) along with previous invasive dental treatment were the most common characteristics of the previously reported cases who developed ONJ during osteoporosis treatment. ${ }^{[6,7]}$ By collaborating with dental surgeons, we made a detailed differential diagnosis in this patient and excluded other possibilities, such as periodontitis, osteomyelitis, periapical disease, gingivitis, tumors or metastasis, and temporomandibular joint disease.

Although the exact mechanism of ONJ remains unknown, suppression of bone remodeling and angiogenesis as well as toxic effects due to oral epithelium seem to be responsible. ${ }^{[8,9]}$ Bisphosphonates substantially reduce bone turnover, impairing the repair of microdamage. They also cause increased bone mineralization which increases the bone brittleness. The microdamage and microfractures that occur either physiologically as the result of the constant stress of masticatory forces or pathologically as the result of local infections and dental extractions cannot be repaired. The impaired bone architecture and quality increases bone fragility, finally leading to the development of ONJ. ${ }^{[8,9]}$ Infections generally accompany ONJ, which not only increases the tendency for ONJ development, but also exacerbates the clinical symptoms. Likewise, it is well known that ONJ may be asymptomatic in early stages. These symptoms mostly occur due to secondary infections, ${ }^{[9,10]}$ as was observed in the present case. Osteonecrosis of the jaw preferentially involves the bones that have a high intracortical remodeling rate, which explains why it occurs mostly in the mandible (70\%) and less frequently in the maxilla $(30 \%){ }^{[9,10]}$

The development of ONJ has not been known to be directly caused by the presence of AS nor by treatment with etanercept. Dental tooth extraction seemed to be the main triggering factor for $\mathrm{ONJ}$ in our patient. Comorbid diseases or other concomitant medications should also be considered as potential precipitating factors; however, our case did not have any comorbid diseases. With respect to concomitant medications, corticosteroids and immunosupressive agents are reported to contribute to osteonecrosis development. ${ }^{[1]}$ Therefore, the past history of intermittent corticosteroid use in our patient should also be kept in mind. Besides, thrombogenic aPL antibodies may also precipitate osteonecrosis; ${ }^{[12]}$ however, our patient was negative for these antibodies.

To our knowledge, ONJ should not be included as one of the complications of anti-TNF agents. In our case, etanercept treatment cannot be hold responsible from the occurrence of the ONJ complication. If anti-TNF agents really facilitated ONJ development, this effect could not be explained solely by causing a tendency toward infection. Anti-TNF agents are well known to cause a modest increase in bone formation and suppression in bone resorption. ${ }^{[13]}$ Consequently, this resorption may contribute to ONJ development. Evidence supporting this assumption comes from the fact that anti-RANKL (receptor activator of nuclear factor- $\mathrm{kB}$ ligand) antibody (denosumab) treatment for osteoporosis may also induce osteonecrosis development, which is similar to that of bisphosphonates. ${ }^{[14]}$ This may imply that any therapeutic agent which suppresses bone resorption, including etanercept and denosumab, may facilitate osteonecrosis development.

The management of ONJ is initially conservative, including ending the bisphosphonate treatment, eliminating pain, controlling the infection, and preventing the progression of osteonecrosis. ${ }^{[9-10]}$ A good oral hygiene regimen with oral antimicrobial rinses is necessary. Identifying the stage of $\mathrm{ONJ}$ is also important for determining proper management. Osteonecrosis of the jaw is classified as having stages from 0 to 3 according to clinical signs and symptoms. ${ }^{[10]}$ No imaging criteria are used for this classification. Delaying surgical interventions until stage 3 is recommended. If surgery becomes necessary, the necrotic area should be extracted with minimal trauma to surrounding healthy tissues. ${ }^{[10]}$ Our patient was accepted as stage 2 and a conservative approach proved to be sufficient with no surgical treatment needed.

Although the risk of ONJ development is low during osteoporosis treatment, preventive measures should always be considered. Before starting the treatment, a dentist should be consulted and, if needed, should initiate it. It is also recommended that the bisphosphonate treatment be stopped temporarily before a dental surgery. It should only be restarted after complete healing of the bone, especially for patients who received bisphosphonate for more than three years. ${ }^{[8]}$

In conclusion, ONJ development during oral bisphosphonate treatment in osteoporosis patients is 
a very rare, but well-recognized complication. To our knowledge, occurrence of this very rare complication in an osteoporotic patient with AS has not been reported in literature. Although, dental tooth extraction along with long term alendronate treatment seem to be the main causative factors for this patient, the possibility of even a minor contribution of etanercept by means of facilitating oral infection and suppressing bone resorption is speculative. Osteoporosis may commonly accompany AS, and bisphosphonate treatment has a potential to be used in AS, both for disease control and OP treatment. ${ }^{[15]}$ As the use of bisphosphonates in AS patients increases, the incidence of ONJ may also be expected to rise in the future.

\section{Declaration of conflicting interests}

The authors declared no conflicts of interest with respect to the authorship and/or publication of this article.

\section{Funding}

The authors received no financial support for the research and/or authorship of this article.

\section{REFERENCES}

1. Rodan GA, Fleisch HA. Bisphosphonates: mechanisms of action. J Clin Invest 1996;97:2692-6.

2. Graham R, Russell G. Deteminants of structure- function relationships among bisphosphonates. Bone 2007;40:21-5.

3. Ruggiero SL, Mehrotra B, Rosenberg TJ, Engroff SL. Osteonecrosis of the jaws associated with the use of bisphosphonates: a review of 63 cases. J Oral Maxillofac Surg 2004;62:527-34.

4. Khosla S, Burr D, Cauley J, Dempster DW, Ebeling PR, Felsenberg D, et al. Bisphosphonate-associated osteonecrosis of the jaw: report of a task force of the American Society for Bone and Mineral Research. J Bone Miner Res 2007;22:1479-91.
5. Felsenberg D, Hoffmeister B. Necrosis of the jaw after high-dose bisphosphonate therapy. Deatsches Arzteblatt 2006;103:3078.

6. Marx RE, Cillo JE Jr, Ulloa JJ. Oral bisphosphonateinduced osteonecrosis: risk factors, prediction of risk using serum CTX testing, prevention, and treatment. J Oral Maxillofac Surg 2007;65:2397-410.

7. Pazianas M, Miller P, Blumentals WA, Bernal M, Kothawala P. A review of the literature on osteonecrosis of the jaw in patients with osteoporosis treated with oral bisphosphonates: prevalence, risk factors, and clinical characteristics. Clin Ther 2007;29:1548-58.

8. Ruggiero SL, Dodson TB, Assael LA, Landesberg R, Marx RE, Mehrotra B, et al. American Association of Oral and Maxillofacial Surgeons position paper on bisphosphonate-related osteonecrosis of the jaws-2009 update. J Oral Maxillofac Surg 2009;67:2-12.

9. Turner $\mathrm{CH}$. Biomechanics of bone: determinants of skeletal fragility and bone quality. Osteoporos Int 2002;13:97-104.

10. Capsoni F, Longhi M, Weinstein R. Bisphosphonateassociated osteonecrosis of the jaw: the rheumatologist's role. Arthritis Res Ther 2006;8:219.

11. Assael LA. Oral bisphosphonates as a cause of bisphosphonate-related osteonecrosis of the jaws: clinical findings, assessment of risks, and preventive strategies. J Oral Maxillofac Surg 2009;67:35-43.

12. Erkan D, Lockshin MD. Antiphospholipid syndrome. Curr Opin Rheumatol 2006;18:242-8.

13. Seriolo B, Paolino S, Sulli A, Ferretti V, Cutolo M. Bone metabolism changes during anti-TNF-alpha therapy in patients with active rheumatoid arthritis. Ann N Y Acad Sci 2006;1069:420-7.

14. Taylor KH, Middlefell LS, Mizen KD. Osteonecrosis of the jaws induced by anti-RANK ligand therapy. Br J Oral Maxillofac Surg 2010;48:221-3.

15. Toussirot E, Wendling D. Antiinflammatory treatment with bisphosphonates in ankylosing spondylitis. Curr Opin Rheumatol 2007;19:340-5. 